\title{
Contribution of Terrestrial Runoff to Coral Disease Prevalence on North Bali's Massive Porites
}

\author{
I Gusti Bagus Siladharma and Widiastuti Karim* \\ Department of Marine Science, Faculty of Marine and Fisheries, Udayana University, \\ Bukit Jimbaran Campus, Badung, Bali, 80361 Indonesia \\ Email: widiastutikarim@unud.ac.id
}

\begin{abstract}
The widespread of coral disease may threatened Bali's marine tourism which is the main asset for the nation prosperity. However, the disease prevalence is still unknown, in particular inshore coral reefs near to tourist spot areas. Therefore, the research aims to investigate the contribution of terrestrial runoff to coral disease prevalence and to examine the relationships between disease prevalence and environmental parameters (nitrate, phosphate, organic carbon and total suspended solids (TSS)) within the population of massive Porites on shallow north Bali reefs. Syndrome, diseases and healthy colonies of massive Porites coral were counted and noted within a $2 \times 10 \mathrm{~m}$ belt transect at 3 sampling sites. The dominant disease observed was ulcerative white spots (UWS), while the syndromes were pigmentation response and aggressive overgrowth by macroalgae. The highest mean UWS prevalence was at site 3 which was the closest site to runoff (prevalence $=91 \%$ ). This disease only affected one colony at site 1 and 2, respectively. Disease prevalence had strong relationship with TSS and nitrate, yet it showed weak relationship with phosphate and organic carbon. These results suggest that terrestrial runoff could contribute to the disease prevalence by increasing the TSS, nutrients and organic carbon loading to the inshore ecosystems. High level of organic carbon could severe the disease, particularly when combined with elevated TSS and nutrient, by reducing the coral`s immunity system.
\end{abstract}

Keywords: coral disease, prevalence, terrestrial runoff, massive Porites, ulcerative white spots, environmental parameter, North Bali.

\section{Introduction}

There was approximately $24 \%$ of coral reef population worldwide is in vulnerable condition due to the combination of human disturbances (Wilkinson, 2004) and climate change (Gardener et al., 2003; Bruno and Selig 2007; Veron et al., 2009). Among these factors, disease has emerged as one of the most substantial causes for coral reef declining (Rosenberg et al., 2007; Bourne et al., 2009). This pandemic was early documented in Caribbean reefs which affected more than 95\% of its population (Aronson and Precht, 2001; Weil et al., 2006). However, studies lately reported that the outbreak has spread over other part of world reefs, including Indo-Pacific reefs (Raymundo et al., 2005; Haapkylä et al., 2007) in which may not be well documented.

Despite the massive outbreak, the mechanism of disease virulence is still unknown. Field and experimental studies showed that the disease was strongly associated with nutrient enhancement (Kuta and Richardson, 2002; Bruno et al., 2003; Voss and Richardson, 2006), organic carbon (Kuntz et al., 2005; Kline et al., 2006; Baker et al., 2007), and sedimentation (Hodgson, 1990; Pollock et al., 2014).
The high level of nutrient is assumed to decrease the coral immune system, causing reduced defense mechanism against the overgrowth of opportunistic microorganisms (Voss and Richardson, 2006). An experiment with different concentration regimes of organic carbon and nutrients indicated that organic carbon had more adverse impact than nutrient to coral mortality by accelerating the disruption of coral and its microflora mutual partnership (Kline et al., 2006). Meanwhile, increased in suspended solids (TSS) associated with terrestrial runoff reduces the light quality and quantity for coral's photosynthetic microalgae endosymbiont (Symbiodinium sp.), thus lowering the energy production in coral (Falkowski et al., 1990; Richmond, 1993). Coral produces mucus and moves the cilia in order to wipe away the excessive suspended solids which deposited on the coral surface (Furnas, 2003; Devlin and Schaffelke, 2009). As this mechanism costs a lot of energy, coral likely shifts its energy allocation (from grow to defense) making it more vulnerable against infectious microorganisms (Furnas, 2003; Devlin and Schaffelke, 2009). Compared to the effects of nutrients, the relationships between organic carbon and TSS with disease prevalence is not clearly defined yet. 
This study provides preliminary information regarding the distribution, environmental stressors and prevalence of coral disease in north Bali island. As a world tourist destination, Bali is facing pressures from rapid economy growth, overfishing, climate change (Knight et al., 1997). Pemuteran village in north Bali was chosen regarding its location as one of few tourist spots in the north Bali (Figure 1.). Despite its beautiful underwater world, this village suffers from flood in almost every rainy season which hit the highway, villages and affects the surrounding coastal areas through terrestrial runoff and rivers (Gerogak district). In addition to flood, overfishing and coastal development for tourist facilities also threatened this area. The aim of this research is to investigates the contribution of terrestrial runoff to coral disease prevalence and to examine the relationships between coral disease prevalence, nutrients, organic carbon and TSS within population of Indo-Pasific reef main builder species (massive Porites) on shallow north Bali reef.

\section{Materials and Methods}

\section{Sampling sites and environmental parameters}

Prior to investigation, reefs were selected based on its proximity to terrestrial runoff, river, human population and tourist facilities (hotel). The study sites were located in Selini beach, Pemuteran village, Gerogak district, Buleleng regency, north Bali island (Figure 1.). The sampling sites have similar geomorphology and ecology with fringing reefs along the beach. Sampling was conducted using SCUBA in the dry season (September 2016). Site 3 was the only site which has populated area, hotel and river. Moreover, there were three terrestrial runoff in this site which 2 of them were still actively flow into the sea even in dry season. Each site was separated at $1 \mathrm{~km}$ away three $2 \mathrm{~m} \times 10 \mathrm{~m}$ belt transects which placed randomly at 3-6 $\mathrm{m}$ depth. Diseased, syndrome and healthy colonies of massive Porites coral were counted and noted following the description of Coral Disease Handbook (Raymundo et al., 2008) and Underwater Cards for Assessing Coral Health on Indo-Pacific Reefs (Beeden et al., 2008). Identification of massive Porites was based on Veron (2008) and Suharsono (2008). Disease and syndrome prevalence were calculated by :

\section{Number of diseased colonies per transect \\ Total number of colonies per transect $x 100$}

Each $1500 \mathrm{ml}$ of water samples (two replicates) were collected at $\pm 1 \mathrm{~m}$ above the coral colonies and out of the belt transects for nutrient analysis (nitrate, phosphate), organic carbon and TSS. All samples were taken simultaneously with disease observations. Nitrate was determined by the brucine method and phosphate by the ammonium molybdate method, while organic carbon (total organic carbon/TOC) level was measured by titrimetric method (Strickland and Parsons, 1972). TSS concentration was measured gravimetrically from the weight difference between loaded and unloaded filter paper after drying overnight at $60^{\circ}$ C.A $1000 \mathrm{ml}$ of TSS samples were filtered to the pre-weighed $0.45 \mu \mathrm{m}$ (125 mm diameter, Whatman).

\section{Statistical analyses}

One-way ANOVA was used to statistically assess the differences in disease prevalence between sampling sites. Furthermore, the relationships between disease prevalence and environmental parameters (nutrients, organic carbon and TSS level) were analysed by using simple linear regression. All the statistical analyses were conducted by using Statsoft.

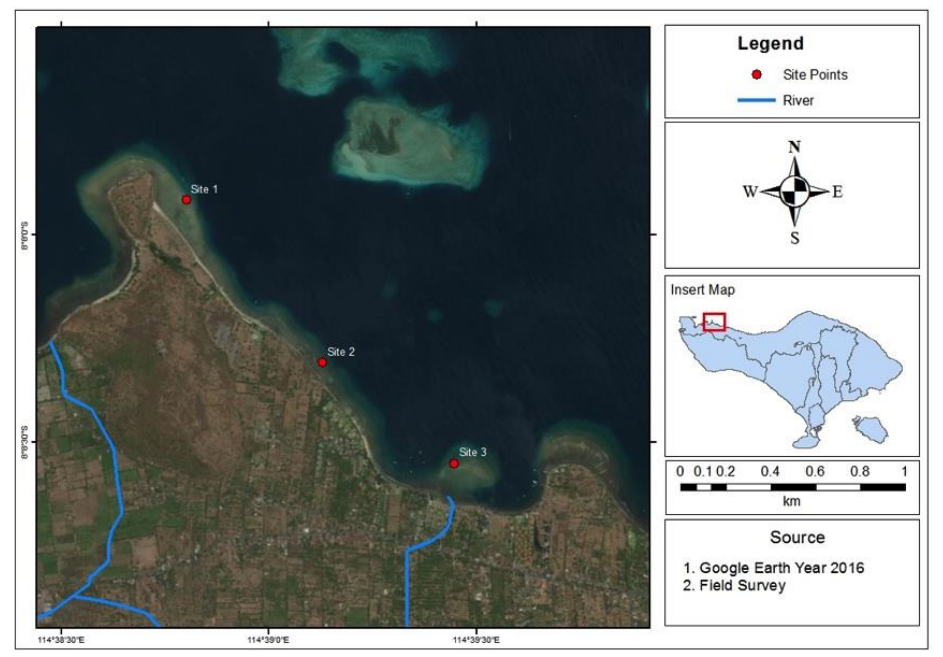

Figure 1. Map of the sampling sites at North of Bali island 


\section{Results and Discussion}

\section{Dynamics of coral disease and syndromes}

Survey observations indicated that some syndromes and disease occurred on massive Porites colonies at the sampling sites (Figure 2). The only dominant disease occurred on massive Porites was ulcerative white spot (UWS), while the syndromes were consisted of aggressive overgrowth of macroalgae, sediment damage, predation by snail, bleaching and pigmentation response. Among these syndromes, pigmentation response and aggressive overgrowth by macroalgae were classified as the most common syndrome particularly in massive Porites colonies. UWS has regular round shape, small white spots (diameter $\pm 1 \mathrm{~cm}$ ) that spread over the surface of coral colony. Pigmentation response was documented with the distinctive pink spot which bordered the dead coral skeleton. Another dominant syndromes observed was the aggressive overgrowth of macroalgae on the surface of massive Porites colonies. The outgrowth likely started from the bottom of the coral, and up to the coral surface. Silt accumulation on the coral surface was reported on some colonies mainly at Site 1. The affected tissue was lost and there was mucus secretion over the coral surface. Some colonies of massive Porites suffered from Drupella sp. snail predation. They left significant wide white patch as of tissue lost which commonly seen at the base of the colony. Additionally, few colonies of massive Porites showed stripe or patch of bleached tissue.These bleached tissue were still alive and demonstrated distinct border between healthy and bleaching tissue.

The prevalence of disease and syndrome among sampling sites is presented in Figure 3 . The highest disease prevalence of UWS was found at site 3 that reached $91 \%$ of the massive Porites colonies. In contrast, this disease had very low prevalence at site 1 and 2 with only $3 \%$ infection of one colony in each site. The pigmentation response was the most predominant syndrome found at all sites. The lowest prevalence of pigmentation response was indicated at site 1 (13\%). The aggressive overgrowth of macroalgae was observed as the second largest syndrome at these sampling sites. Similar to UWS and pigmentation response, site 3 indicated as the highest prevalenceof this syndrome that was $46 \%$. The total average number of massive Porites colonies is almost similar across the sites, with 40 colonies for each site 1 and 2, and 44 colonies for site 3 .

\section{Relationship between coral disease and syndromes prevalence and environmental parameters}

The summary of environmental parameters which assumed as the stressors of coral disease and syndromes at the sampling sites is shown in Table 1.
According to the local diving operators, these sampling sites were no longer operated as diving spots and fishing areas since the underwater scenery was not appealing to tourists and suffered from overfishing (pers. comm. 2016). The level of phosphate at site 2 and 3 were as high as $11.6 \mu \mathrm{M}$, and lower at site 1 . The organic carbon (total organic carbon/TOC) was similar at all sampling sites that reached 51 mg. $\mathrm{L}^{-1}$ in average. Similar level of nitrate was observed at site 1 and 2 , but 5 -fold higher at site 3 . The same trend was found in TSS which showed approximately $17 \mathrm{mg} \cdot \mathrm{L}^{-1}$ at both site 1 and 2, but 3 - times higher at site 3 .

The statistical results of regression analyses between these environmental parameters and UWS disease prevalence is shown in Figure 4. It showed that there was a significant strong relationship between disease prevalence (UWS) and TSS concentration $\left(R^{2}=\right.$ 0.99, $P<0.05)$ and nitrate level $\left(R^{2}=0.99, P<0.05\right)$. However, the relationship between UWS prevalence and phosphate $\left(R^{2}=0.3, P>0.05\right)$ and organic carbon (TOC) $\left(R^{2}=0.3, P>0.05\right)$ were weak. On the contrary, the disease prevalence between-sites showed that the prevalence of UWS were significantly different among sampling sites $(P<0.05)$.

The present study reveals that UWS was the only disease affecting massive Porites colonies at Selini beach, Pemuteran village, north Bali island. This disease had also been documented within massive Porites colonies in the Wakatobi Marine Park, south-east Sulawesi, Indonesia (Raymundo et al., 2005) and on Phillipine reefs (Haapkylä et al., 2007). The positively relationship between UWS prevalence and TSS suggests that high level of TSS could intensify the virulence of this disease. Previous study by Pollock et al. (2014) and Miller et al. (2016) also demonstrated that increased turbidity due to high level of TSS significantly elevated the coral disease and compromised health prevalences. The high amount of TSS in the seawater column reduces the light intensity which is needed for coral's photosynthetic endosymbiont. Consequently, it may diminish the supply energy from the photosynthetic algae for coral as the host. Also, the accumulated TSS on coral surface, may provide suitable media for the opportunistic microorganisms to grow (Hodgson, 1990). In order to remove the deposited TSS, coral secretes mucus on its surface. This mucus secretion consumes significant amount of energy that could be invested for growth, defense, and reproduction. Leads coral to be more susceptible to disease virulence. Although samplings were taken during dry season where the rainfall was only $2 \mathrm{~mm}$ (Indonesian Agency for Meteorological, Climatological and Geophysics), the level of TSS at site 3 was still relatively 3 -fold higher than at site 1 and 2 . The high level of TSS at site 3 was likely due to the two of three runoff and small river that 


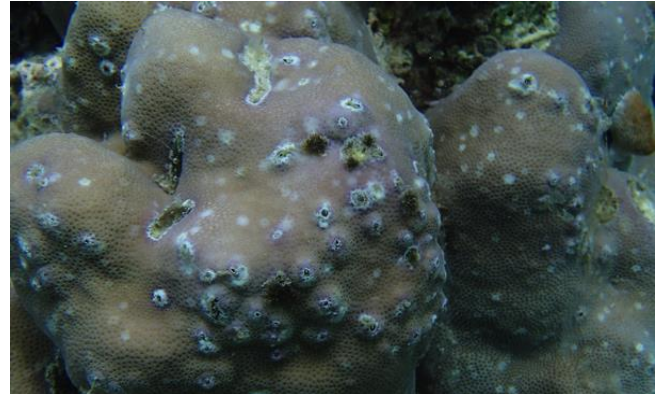

(a)

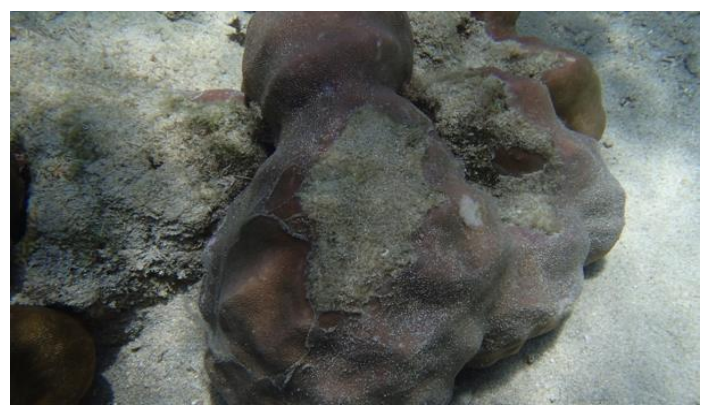

(c)

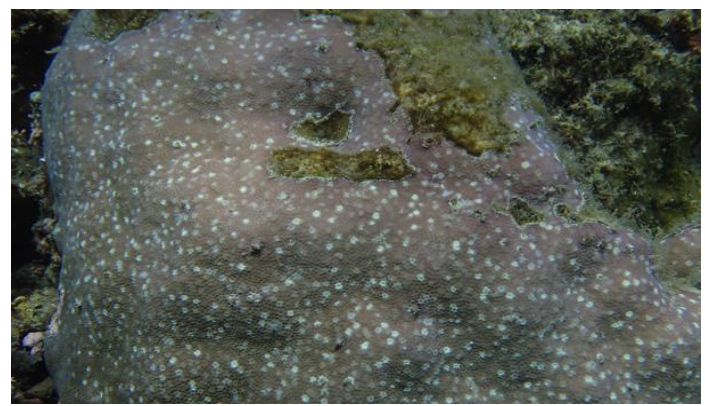

(e)

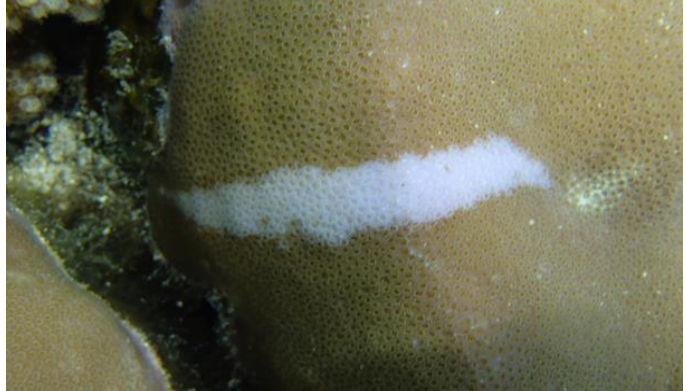

(b)

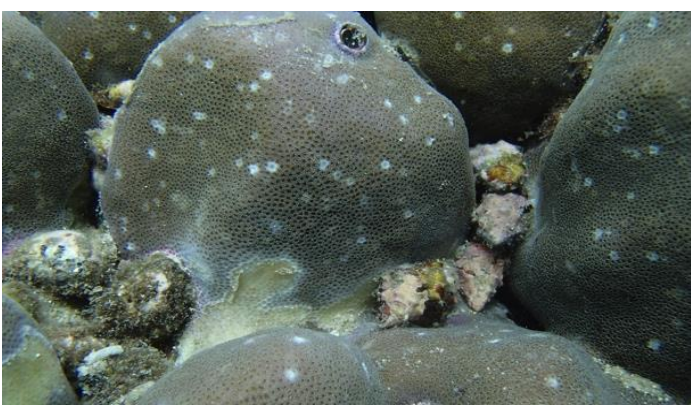

(d)

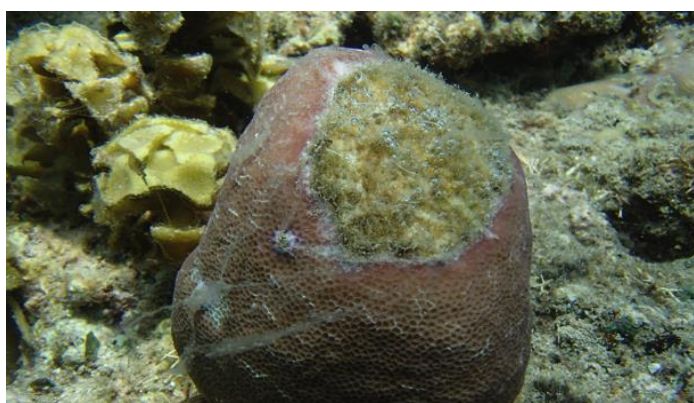

(f)

Figure 2. Diseases and syndromes affecting massive Porites colonies at sampling sites. (a) Pigmentation response; arrows pointing at affected tissue. (b) Unusual bleaching pattern (c) Silt deposition on the surface of massive Porites. (d) Predation by Drupella sp. snail. (e) UWS disease (f) Aggressive overgrowth by macroalgae.

were still actively loading particulate materials and sediments from the land to the surrounding coastal areas. In addition, low resuspension during dry season causes the high amount of TSS in water column.

The amount of nutrient (nitrate) in this study was significantly related to the disease prevalence. Although phosphate showed statistically no relationship with the disease prevalence, the concentration in all the sampling sites was significantly high. The concentration of nitrate measured at all the sampling sites was much higher than those in Kline et al. (2006) which the maximum concentration $(6.5 \mu \mathrm{M})$ was the minimum concentration detected at site 1 .

Likewise for nitrate, the maximum level of phosphate tested at experimental study by Kline et al. (2006) was 2-fold higher at nearly all the sampling sites. The high nutrients amount at all sampling sites were likely the contributor of disease and syndromes appeared at these sampling sites. The finding in the present study is in agreement with Haapkylä et al. (2011) and Kaczmarsky and Richardson (2010) that argued nutrient enhancement promotes the coral disease prevalence, since nutrient is the limited growth factor for microorganisms. However, in relation to the high UWS prevalence at site 3 , it is assumed that nutrient has to couple with other stressors in order to accelerate the disease severity. Kline et al. (2006) showed the effect of nutrients (nitrate, phosphate, ammonia) to coral disease were less harmful than organic carbon.

Despite no strong relationship between disease prevalence and organic carbon at the sampling sites, the level of water column organic carbon in this study was 2-times higher than those in Kuntz et al. (2005). Therefore, organic carbon alone could enhance the 
ILMU KELAUTAN December 2017 Vol 22(4): 193-200

Table 1. Environmental parameters along the sampling sites

\begin{tabular}{crrrrrr}
\hline Station & $\mathrm{Km}^{1}$ & \% UWS & Nitrate $(\mu \mathrm{M})$ & Phosphate $(\mu \mathrm{M})$ & TOC $\left(\mathrm{mg} . \mathrm{L}^{-1}\right)$ & TSS $_{\left(\mathrm{mg} . \mathrm{L}^{-1}\right)}$ \\
\hline 1 & 0 & 3 & 11.3 & 8.4 & 50.6 & 17.2 \\
2 & 1 & 3 & 6.5 & 11.6 & 51.8 & 17.8 \\
3 & 2 & 91 & 48.4 & 11.6 & 50.6 & 53.9 \\
\hline
\end{tabular}

Note.' Km is distance from runoff

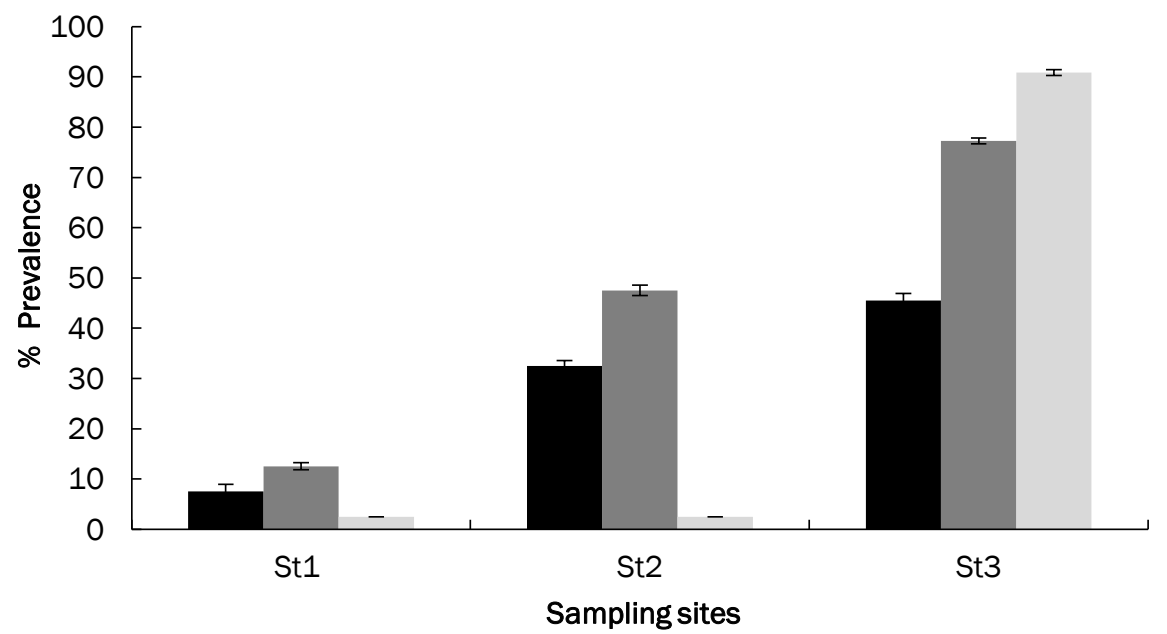

Figure 3. Mean prevalence of the most common disease and syndromes observed on surveyed sampling sites.

Note. $=$ Macroalgae overgrowth; $\square=$ Pigmentation response; $\square=$ UWS

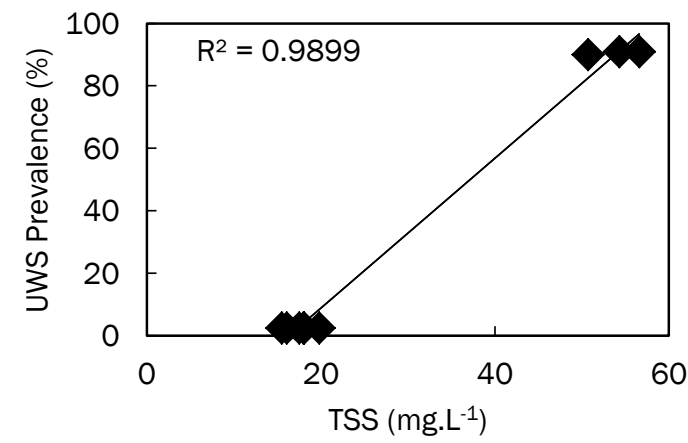

Relationship between UWS prevalence and TSS

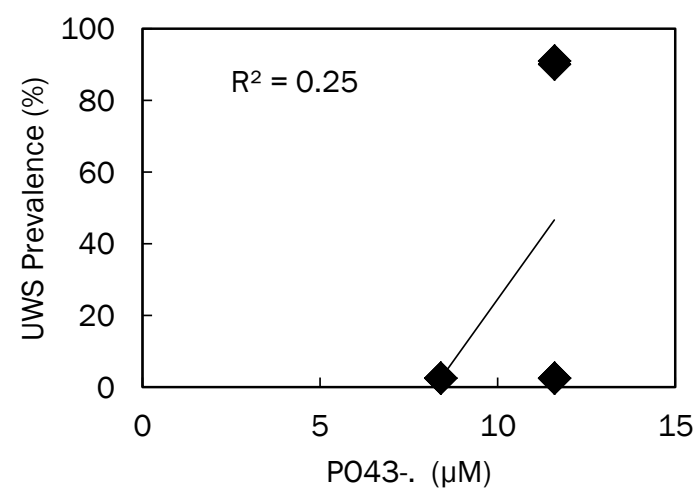

Relationship between UWS prevalence and $\mathrm{PO}_{4}^{3-}$

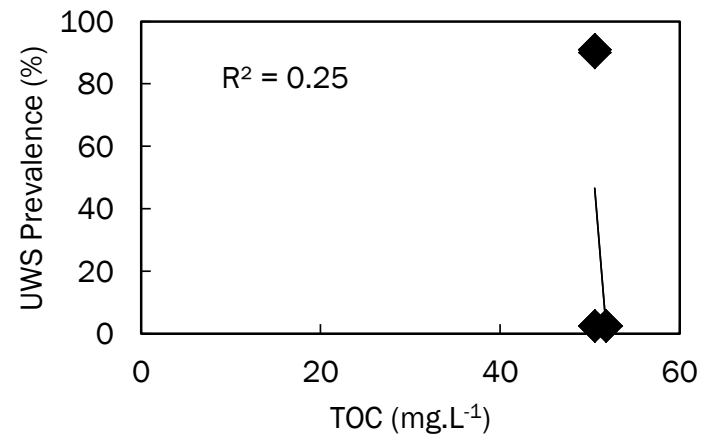

Relationship between UWS prevalence and TOC

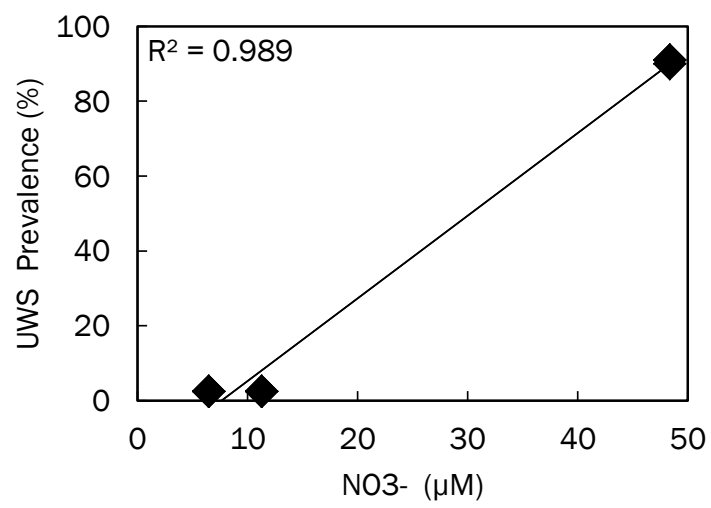

Relationship between UWS prevalence and $\mathrm{NO}_{3}^{-}$.

Figure 4. Analyses of linear regression of relationship between UWS disease prevalence and environmental parameters. 
disease prevalence. The village and hotel may be the source of elevated nutrients and organic carbon to the sampling sites as their sewage effluents and wastewater flow into terrestrial runoff and river. Furthermore, the presence of organic carbon in the water column is indirect effect of elevated level of nutrients. As nutrient increased, the macroalgae population on the coral reefs overgrow and release organic carbon as the photosynthetic product (Smith et al., 2006) or even from dead tissue (Khailov and Burlakova, 1989).

This hypothesis was supported by the large number of overgrowth macroalgae found at the sampling sites, in particular site 3 . The overgrowth of macroalgae might be the result of overfishing of herbivore fish in this area since there were very few coral fish detected during surveys. Nonetheless, this study only tested for the level of total organic carbon, investigation on the effect of high concentration of particulated organic carbon (POC) and dissolved organic carbon (DOC) caused massive prevalence of atramentous necrosis disease (Haapkylä et al., 2011). High level of organic carbon could severe the disease, particularly when combined with elevated TSS and nutrient, by reducing the coral`s immunity system.

This preliminary study with limited dataset presented initial report regarding the status of UWS disease in Indonesia which has not been fully investigated before, except the report by Haapkylä et al. (2007) in Wakatobi Marine Park, South-East Sulawesi. On the contrary, this infectious disease has been widely observed in the Phillipines reefs which share the same geographic region with Indonesia (Raymundo et al., 2005; Kaczmarsky, 2006). Studies by Arboleda and Reichardt (Arboleda and Reichardt, 2010) in infected UWS Porites cylindrica collected from the Phillipines showed that the agent of the disease was Vibrio sp. which is widespread where organic matter is abundant (Colwell, 1996; Reichardt and Jacinto, 2007). Additionally, the seawater temperature when the sampling conducted was $31^{\circ} \mathrm{C}$, an ideal temperature for the Vibrio $\mathrm{sp}$. to proliferate (Colwell 1996; Reichardt and Jacinto, 2007). Therefore, it is suggested that together with the poor water quality densed human population and seawater temperature would allow the disease agent to grow rapidly at site 3 .

As UWS is an infectious disease, wider investigations on adjacent reefs should be conducted in order to understand the variability of species prevalence and environmental stressors. Indonesia, particularly north Bali island, has distinct geography and environment, thus the disease agent and the reefs capability to recover from this disease should be monitored. Since Porites is the most preeminent coral builder species in Indo-Pasific coral reefs (Veron, 2008), UWS disease pandemic can significantly degrade the reef ecosystem. The finding of this study was supported by previous studies that disease prevalence, particularly UWS, is strongly related to anthropogenic activities (Raymundo et al., 2005; Voss and Richardson 2006; Bruno and Selig, 2007; Kaczmarsky and Richardson, 2010).

\section{Conclusion}

This study provides preliminary information regarding the distribution, environmental stressors and prevalence of coral disease in north Bali island (study case: Selini beach, Pemuteran village). Ulcerative white spot (UWS) was the only disease affecting massive Porites colonies at the study sites. The present study reveals that terrestrial runoff could contribute to the disease prevalence by increasing the TSS, nutrients and organic carbon loading to the inshore ecosystems. This finding suggests that important consideration of water quality of terrestrial runoff and river which could deliver significant amount of disease drivers to the inshore areas could prevent the collapse of coral reef ecosystems and its social economic impacts, especially in Bali's marine tourism.

\section{Acknowledgments}

We thank two anonymous reviewers for constructive comments on the manuscript. The authors wish to thank: Nidzar Muhammad Rafly, Putu Hernanda Krishna Ariszandy and Dika Madyawan for sampling assistances; Ni Wayan Gita Kanela and Naila Makfiya for TSS analyses. Marine Laboratory at Faculty of Marine and Fisheries, Udayana University for logistical supports. This study was funded by grants from Udayana University to I.G.B.S. and W.K.

\section{References}

Arboleda, M.D.M. \& Reichardt, W.T. 2010. Vibrio sp. causing Porites Ulcerative White Spot Disease. Dis. Aqua. Organ. 90:93-104. doi: 10.3354/ dao02222.

Aronson, R. \& Precht, W. 2001. White-band disease and the changing face of Caribbean coral reefs. Hydrobiologia. 460:4-38. doi: https://doi.org/10. 1023/A:1013103928980

Baker, D.M., MacAvoy, S.E. \& Kim, K. 2007. Relationship between water quality, $\delta 15 \mathrm{~N}$, and aspergillosis of Caribbean sea fan corals. Mar. Ecol. Prog. Ser. 343:123-130. doi: https://doi. org / 10.3354/meps06937

Beeden, R., Willis, B.L., Raymundo, L.J., Page, C.A. \& Weil, E. 2008. Underwater Cards for Assessing Coral Health on Indo-Pacific Reefs. The University 
of Queensland, St Lucia, Queensland, Australia. $26 \mathrm{p}$.

Bourne, D.G., Garren, M., Work, T.M., Rosenberg, E., Smith, G.W. \& Harvell, C.D. 2009, Microbial disease and the coral holobiont. Trends Microbiol. 17:554-562. doi: 10.1016/j.tim.2009.09.004

Bruno, J.F. \& Selig, E.R. 2007. Regional decline of coral cover in the Indo-Pacific: timing, extent, and subregional comparisons PLoS One.2:e711. doi:10.1371/journal.pone.0000711.

Bruno, J.F. Petes, L.E., Harvell, C.D. \& Hettinger, A. 2003. Nutrient enrichment can increase the severity of coral diseases. Ecol. Letters. 6: 10561061. doi:10.1046/j.1461-0248.2003.00544.x

Colwell, R.R. 1996. Global climate and infectious disease: the cholera paradigm. Science. 274:2025-2031.

Devlin, M. \& Schaffelke, B. 2009. Spatial extent of riverine flood plumes and exposure of marine ecosystems in the Tully coastal region, Great Barrier Reef. Mar. Freshwat. Res. 60(11): 1109-1122. doi: https://doi.org/10.1071/MF08 343

Falkowski, P.G., Jokiel, P.L. \& Kinzie, R.A. 1990. Irradiance and corals. In: Z. Dubinsky. Ecosystems of the World: Coral Reefs. Elsevier, Amsterdam. pp. 89-107.

Furnas, M. 2003. Catchment and corals: terrestrial runoff to the Great Barrier Reef, Australian Institute of Marine Science, Townsville.

Gardener, T., Cote, I.M., Gill, J.A., Grant, A. \& Watkinson, A.R. 2003. Long-term regionwide declines in Caribbean corals. Science. 301:958960.doi:10.1126/science.1086050.

Haapkylä, J., Seymour, A.S., Trebilco, J.\& Smith, D. 2007. Coral disease prevalence and coral health in the Wakatobi Marine Park, south-east Sulawesi, Indonesia. J. Mar. Biol. Assoc. U.K. 87(2):403-414. doi: https://doi.org/10.1017/ S0025315407055828

Haapkylä, J., Unsworth, R.K., Flavell, M., Bourne, D.G., Schaffelke, B. \& Willis, B.L. 2011. Seasonal rainfall and runoff promote coral disease on an inshore reef. PLoS One. 6(2):e16893. doi: https://doi.org/10.1371/journal.pone.0016893

Hodgson, G. 1990. Tetracycline reduces sedimentation damage to corals. Mar. Biol. 104:493-496. doi: https://doi.org/10.1007/BF01314355
Kaczmarsky, L.T. 2006. Coral disease dynamics in the central Philippines. Dis. Aqua. Organ. 69:9-21. doi: 10.3354/dao069009

Kaczmarsky, L.\& Richardson, L.L. 2010. Do elevated nutrients and organic carbon on Philippine reefs increase the prevalence of coral disease? Coral Reefs. 30:253-257. doi: https://doi.org/10. $1007 /$ s00338-010-0686-2

Kecamatan Gerokgak, Banjir di Desa Pemuteran 2016. Available from: https://gerokgak. bulelengkab.go.id/berita/banjir-di-desa-pemutera n-79. [26 April 2017].

Khailov, K.M. \& Burlakova, Z.P. 1989. Release of dissolved organic matter by marine seaweeds and distribution of their total organic production to inshore communities. Limnol. Oceanog. 14:521-527. doi: 10.4319/lo.1969.14.4.0521

Kline, D.I., Kuntz, N.M., Breitbart, M., Knowlton, N.\& Rohwer, F. 2006. Role of elevated organic carbon levels and microbial activity in coral mortality.Mar. Ecol. Prog. Ser. 314:119-125. doi:10.3354/ meps314119

Kuntz, N.M., Kline, D.I., Sandin, S.A.\& Rohwer, F. 2005, Pathologies and mortality rates caused by organic carbon and nutrient stressors in three Caribbean coral species.Mar. Ecol. Prog. Ser. 294:173-180.

Knight, D., LeDrew, E. \& Holden, H. 1997. Mapping submerged corals in Fiji from remote sensing an in situ measurements: applications for integrated coastal management. Ocean. Coast. Manag. 34(2):153161-159170. doi: https://doi.org/10. 1016/S0964-5691(97)00001-X

Kuta, K.G. \& Richardson, L.L. 2002. Ecological aspects of black band disease of corals: relationships between disease prevalence and environmental factors. Coral Reefs. 21:393-398. doi: $10.1007 / \mathrm{s} 00338-002-0261-6$

Miller, M.W., Karazsia, J., Groves, C.E., Griffin, S., Moore, T., Wilber, P. \& Gregg, K. 2016. Detecting sedimentation impacts to coral reefs resulting from dredging the Port of Miami, Florida USA. PeerJ. 4: e2711. doi: https://doi.org/10.7717/ peerj.2711

Pollock, F.J., Lamb, J.B., Field, S.N., Heron, S.F., Schaffelke, B., Shedrawi, G., Bourne, D.G. \& Willis, B.L. 2014. Sediment and turbidity associated with offshore dredging increase coral disease prevalence on nearby reefs. PLOS one, 9(7): e102498. doi: https://doi.org/10.1371/journal. pone.0102498 
Raymundo, L.J., Reboton, C.T., Rosell, K.B. \& Kaczmarsky, L. 2005. Coral diseases on Philippine reefs: genus Porites is a dominant host. Dis. Aqua. Organ. 64:181-191. doi: 10.3354/ dao064181

Raymundo, L.J., Couch, C.S., Bruckner, A.W.,Harvell, C.D., Work, T.M., Weil, E., Woodley, C.M., Jordan-Dahlgren, E., Willis, B.L., Sato, Y.\& Aeby, G.S. 2008. Coral Disease Handbook Guidelines for Assessment, Monitoring and Management, The University of Queensland, St. Lucia, Australia.

Reichardt, W. \& Jacinto, G.S. 2007. Organic pollution and its impact on the microbiology of coastal marine environments: a Philippine perspective. Asian J. Wat. Environ. Poll. 4(1):1-9.

Richmond, R.H. 1993. Coral reefs: present problems and future concerns resulting from anthropogenic disturbance. American Zoolog.(33):524-536.

Rosenberg, E, Kelloff, C.A. \& Rohwer, F. 2007. Coral microbiology.Oceanograp.(20):146-154. doi: http://dx.doi.org/10.5670/oceanog.2007.60

Smith, J.E., Shaw, M., Edwards, R.A., Obura, D., Pantos, O., Sala, E., Sandin, S.A., Smriga, S., Hatay, M.\& Rohwer, F.L. 2006. Indirect effects of algae on coral: Algae-mediated, microbe-induced coral mortality. Ecol. Lett. 9:835-845. doi: 10.1111/j.1461-0248.2006.00937.x
Strickland, J.D. \& Parsons, T.R. 1972. A practical handbook of seawater analysis, 2nd edn, Ottawa, Canada.

Suharsono. 2008, Jenis-Jenis Karang di Indonesia, LIPI Press, Jakarta.

Veron, J.E.N. 2008. Corals of the World, Australian Institute of Marine Science, Townsville, Australia.

Veron, J.E.N. Hoegh-Guldberg, O., Lenton, T.M., Lough, J.M., Obura, D.O., Pearce-Kelly, P, Sheppard, C.R.C., Spalding, M., Stafford-Smith M.G. \& Rogers, A.D. 2009. The coral reef crisis: The critical importance of $<350 \mathrm{ppm} \mathrm{CO}_{2}$. Mar. Poll. Bull. 58(10): 1428-1436. doi: 10.1016/j.mar polbul.2009.09.009.

Voss, J.D. \& Richardson, L.L. 2006. Coral diseases near Lee Stocking Island, Bahamas: patterns and potential drivers. Dis. Aquat. Organ. 69:33-40. doi: 10.3354/dao069033

Weil, E., Smith, G. \& Gil-Agudelo, D.L. 2006. Status and progress in coral reef disease research. Dis. Aquat. Organ. 69:1-7. doi: 10.3354/dao069001

Wilkinson, C. 2004. Status of coral reefs of the world, Australian Institute of Marine Science. Townsville, Australia. 